\title{
Does Stock Market Performance Affect Economic Growth? Empirical Evidence from Saudi Arabia
}

\author{
Moayad H. Al Rasasi ${ }^{1}$, Soleman O. Alsabban ${ }^{1} \&$ Omar A. Alarfaj ${ }^{1}$ \\ ${ }^{1}$ Economic Research Department, Saudi Arabian Monetary Authority, Riyadh, Saudi Arabia \\ Correspondence: Moayad Al Rasasi, Economic Research Department, Saudi Arabian Monetary Authority, \\ Riyadh, Saudi Arabia. E-mail: moalrasasi@gmail.com
}

Received: July 27, 2019

Accepted: August 9, 2019

Online Published: August 10, 2019

doi:10.5539/ijef.v11n9p21

URL: https://doi.org/10.5539/ijef.v11n9p21

\begin{abstract}
This research paper investigates the impact of stock prices on real economic activity in the Saudi Arabian economy. We utilize various econometric techniques - Johansen and Juselius's (1990) cointegration tests and Granger's (1969) causality test - to assess such a relationship, based on quarterly observations spanning the period from the first quarter of 2010 to the fourth quarter of 2018. Our empirical evidence indicates the presence of a significant cointegrating relationship between the two variables being examined; in other words, stock prices have a significant impact on real economic growth. Specifically, the estimated long-run relationship reveals that a 1 percent increase in stock prices would boost economic growth by 0.32 percent. In addition, the error correction model suggests that when the economy deviates from its steady state condition, it needs about a year and a half to return to its equilibrium condition. Lastly, this paper applies the most common Granger causality test, which confirms the essential role of stock prices in predicting changes in economic growth.
\end{abstract}

Keywords: stock market, economic growth, causality analysis, cointegration, Saudi Arabia

\section{Introduction}

Stock market prices play an important and necessary role in the economy, and may even be a leading indicator of economic growth, according to fundamental studies such as Fama (1981, 1990), Geske and Roll (1983), Schwert (1990), and Barro (1990). Traditional theories of finance indicate that higher stock prices are considered to be an incentive or stimulus for firms and households participating in stock markets. Those theories suggest that stock markets can essentially be seen as an indicator of the general state of the economy by which stock performance influences the real economy through a confidence channel. Higher stock prices can lead to higher confidence and possibly reduce the uncertainty of firms and households regarding future economic conditions. In addition, better stock market performance induces higher expected profits, which ultimately increases the amount of internal finance available for investment (Note 1). Therefore, economists and financial market experts have proposed theories about the channels by which stock prices are transmitted into the real economy. For instance, Tobin (1969) proposed "Tobin's Q", which is a coefficient or ratio illustrating the impact of a share's current market value on the cost of replacement capital. A High Tobin's Q indicates high investment expenditures, which lead to high aggregate economic output, since firms can finance their investment projects more easily with a high share price. Alternatively, Modigliani (1971) theorized that the stock market influences real economic activity via the consumption channel. According to this theory, stock market performance might influence consumption as one of the key channels affecting real economic activities given that a good performance or higher stock value increases households' wealth or permanent income, which in turn will lead households to re-adjust their consumption level. In addition, Gertler and Bernanke (1989) and Kiyotaki and Moore (1997) introduced the financial accelerator theory, which supports the strong linkage between stock markets and real activity. The theory of the financial accelerator focuses on how a firm's stock price affects its balance sheet. Given the presence of asymmetric information in the credit markets, a firm's ability to borrow money will depend on the value of its collateral used to obtain a loan. The firm's collateral value might appreciate in scenarios where its stock value appreciates. A higher collateral value will lead to higher credits used for investment purposes, which will lead to an expansion of real economic activity.

In turn, some economists and financial experts have tested these theories on various economies across the globe. There is a vast literature assessing empirically, through the application of various econometric techniques, 
whether changes in overall stock market performance influence real economic activity. This literature tends to have mixed results: while some research (e.g. Fama, 1981, 1990; Schwert, 1990; Barro, 1990; Mauro, 2003; Humpe \& Macmillan, 2005) confirms the existence of the relationship between stock market returns and future real economic activity, other studies (e.g. Binswanger 2000, 2004) do not see such a relationship.

With this background in mind, it could be inferred that financial markets play a role in influencing various economic activities through multiple channels, as mentioned above. However, to our knowledge, none of the existing research investigated the relationship between stock market performance and economic activity in Saudi Arabia (Note 2). This in turn motivates us to assess whether such an important relationship exists for the Saudi economy. In doing so, this study will contribute to the existing literature in several ways. First, given the size of the Saudi economy, and the fact that its stock market is one of the largest in the MENA region, there is inadequate coverage in the literature of the role of the stock market in promoting economic growth in Saudi Arabia. In addition, the recent inclusion of the Saudi stock market in emerging market indices such as FTSE Russell and Morgan Stanley Capital International (MSCI) points to the importance of assessing the impact of the stock market on the real economy. Therefore, this study aims to fill the gap in the literature by focusing on Saudi Arabia. Furthermore, it is crucial to emphasize that the 2008-09 global financial crisis provided an informative case study for policymakers, who were able to observe in a substantial number of countries the decline in economic activity resulting from the crisis. Lastly, this research paper draws attention to the important role of the stock market in achieving Saudi Vision 2030's objective to develop an advanced capital market, which is one of the three main pillars underpinning the financial sector development program (FSDP).

Therefore, this research paper aims to determine if the traditional finance theory mentioned earlier holds in the Saudi Arabian economy. Specifically, is a higher Saudi stock market performance a leading indicator for faster economic growth? To test this proposition, various econometric procedures are conducted based on the obtained data.

The paper has five sections, which are organized as follows. Section 2 summarizes the relevant research findings. Section 3 presents the dataset that is utilized, and Section 4 discusses the empirical methodology and analysis. Section 5 summarizes and concludes the main findings of the paper.

\section{Literature Review}

Several studies have been put forward supporting the role of stock market performance (i.e. stock prices) as a leading indicator for economic activity. For instance, Choi et al. (1999) examine the significance of real stock returns in explaining current growth rates of industrial production by relying on monthly data of the G7 countries. The authors apply the popular two-step cointegration test developed by Engle and Granger (1987). Their empirical analysis reveals that stock returns Granger cause real economic activity to grow in all the G7 countries with the exception of Italy.

Similarly, Duca (2007) adopts the Granger (1969) causality technique to examine the relationship between stock market indices and economic growth in the top five stock markets of the world (France, Germany, Japan, the US, and the UK), characterized by market capitalization. His analysis is based on quarterly data from 1957 to 2005 , with some countries having a smaller sample size based on the availability of data. The empirical analysis confirms the existence of a causal relationship between the stock market and economic growth - that is, there is unidirectional causality - in the US, Japan, France, and the UK. On the other hand, no similar causal relationship is apparent in Germany.

In the case of Turkey, Kaplan (2008) examines the empirical association between stock returns and real economic growth by implementing a Granger (1969) causality test with quarterly data from 1987:Q1 to 2006:Q4. The test results show that there is a strong and statistically significant relationship between stock market prices and real economic growth in Turkey based on the implemented cointegration tests of Johansen and Juselius (1990). In addition, the author finds that changes in stock prices are able to capture changes in real economic growth; in other words, there is a unidirectional causality running from stock prices to economic growth. Similarly, Basdas and Soytas (2009) use monthly data for Turkey covering the period from January 1997 to June 2008 with the objective of investigating the possible correlation between stock market returns and economic growth, while taking into account interest rates on deposits and inflation. To meet this objective, the authors carry out their investigation based on the Granger (1969) causality test, which is performed based on a vector autoregressive model. Their results indicate that real interest rates and real stock returns Granger cause real growth, and not the other way around. Perhaps it is worth noting that their results for the period 2002-08 indicate that the relationship between real growth and real stock returns is questionable. They argue that the link between the stock market and economic growth is weak and inadequate because of increasing foreign share in the 
Istanbul Stock Exchange. This argument is somewhat obvious in the sense that an increased foreign share in any given stock exchange makes the share price of domestic firms more dependent on foreign sales and foreign economies.

Tsouma (2009) analyzes the dynamic relationship between stock market returns and economic activity in 22 advanced economies and 19 emerging markets using monthly data spanning the period from January 1990 to December 2006. The results obtained from the empirical analysis indicate a strong positive unidirectional relationship between stock returns and economic activity. More precisely, the study finds statistically significant coefficients indicating the existence of such a relationship for 18 mature economies and 15 emerging markets.

In line with the studies mentioned above, Tao et al. (2014) find evidence that supports the notion of a positive correlation between stock market returns and real economic activity in China by utilizing monthly frequencies from January 2001 to December 2013. However, their methodology is somewhat unique in that they utilize different proxies for economic activity - that is, industrial production, employment, investment and consumption demand, and aggregate income. The researchers implemented Granger's (1969) causality test alongside impulse response function (IRF) and forecast error variance decomposition (FEVD) analysis. Their results point to a strong association between China's stock market and real economic activity. Lyocsa et al. (2011) also assess the linkage between stock markets and real economic activity in the Czech Republic, Hungary, Poland, and Slovakia using quarterly data from 1996:Q1 to 2009:Q4. To reach an accurate assessment, the authors apply the causality tests developed by Granger (1969) and Toda-Yamamoto (1995). The obtained results from these tests show that three (Czech Republic, Hungary, Poland, and Slovakia) of the four central European countries studied are in line with the present value theory of stock prices, which indicates that the stock prices in those three countries can be used as leading indicators of real economic activity. In other words, changes in stock markets can predict changes in the real economy in these three countries. Using quarterly data from 2000:Q1 to 2012:Q2 for the advanced economies of the Czech Republic, Germany, Hungary, Japan, Poland, and the US, Krchniva (2016) conducts an empirical analysis using both the Granger (1969) causality test and a Ljung-Box portmanteau test to evaluate the relationship between the stock markets and real economic activity. Both of these analyses show the presence of a strong and statistically significant relationship between the two variables in these countries.

However, conversely, some studies have found no relationship between stock market returns and economic growth. For instance, Binswanger (2000) claims that stock market returns cannot fundamentally explain economic growth since the early 1980s. His results provide evidence that, in the US over the past four decades, the relationship between stock prices and economic activity has diminished. In an extension to this study, Binswanger (2004) investigates the other G7 countries (Japan, Canada, France, the UK, Germany, and Italy). He obtains equivalent results to his US study, indicating that there is no correlation between stock market prices and economic activity. Therefore, he concludes that the debated relationship is thought to be nonexistent, at least between 1980 and 2004. On the same basis, Mao and Wu (2007) find similar results when using monthly data for Australia from January 1974 to July 2004. Their conclusion, based on the Granger (1969) causality test, indicates that there is a bidirectional Granger causality between stock market prices and economic activity; thus, they conclude that there is no clear causal relationship observed in Australia.

It is essential to note that another strand of the literature examines the impact on the financial markets of various economic variables such as exchange rates (Mechri et al., 2019), commodity prices (Guo, 2017), fiscal policy (Chatziantoniou et al., 2013), monetary policy (Ioannidis \& Kontonikas, 2008), and international trade (Manova, 2008).

Unfortunately, despite the extensive research exploring the effects of stock market developments on economic activity, the research devoted to the Saudi economy is scarce. In fact, to our knowledge, there is only a single study probing the effect of stock market fluctuations on the demand for money in Saudi Arabia (Al Rasasi et al., 2019). Other than this study, most of the existing literature attempts to assess the impact of macroeconomic developments on the stock market (Alshogeathri, 2011; Kalyanaraman \& Al Tuwajri, 2014; Mohanty et al., 2018). The gap in the literature motivates us to explore the causal relationship between stock market and real economic activity in Saudi Arabia.

\section{Data}

To conduct our empirical analysis addressing the key objective of this research paper, we rely on two variables. The first variable is the real Saudi non-oil gross domestic product (GDP), which is used as a proxy of real economic activity; the second variable is the Tadawul All Share Index (TASI), used as a proxy of stock market performance. It is also important to highlight that we deflated the TASI index in order to measure the real stock market performance. Likewise, we use the consumer price index (CPI) with the 2013 base year in order to adjust 
TASI for inflation. The utilized dataset consists of quarterly observations covering the period from 2010:Q1 to 2018:Q4, and all data are taken from various sources. The data for real non-oil GDP and CPI are downloaded from the General Authority for Statistics (GASTAT) website, while TASI data are downloaded from the Saudi Stock Exchange (Tadawul) website. Both variables are expressed in natural logarithm form.

\section{Empirical Methodology and Results}

\subsection{Stochastic Properties of the Data}

Checking the stationarity of the economic variables is a key procedure in empirical economic and financial research. This is fundamental in practice, since it enables researchers to avoid inaccurate analysis originating from spurious results. Therefore, there has been ongoing research in developing various tests diagnosing the stochastic properties of the data. Due to this requirement, in evaluating the stationarity of time series data, we rely on some of the most popular tests developed by Phillips and Perron (1981). By conducting this test, we can reach a conclusion indicating that both variables are integrated in order one; in other words, the variables become stationary when the first difference is taken, as summarized in Table 1.

Table 1. Phillips and Perron's (1981) Unit Root Test

\begin{tabular}{lllcc}
\hline & Level Data & \multicolumn{2}{c}{ First Difference } \\
\hline TASI & Constant & Trend & Constant & Trend \\
GDP & -2.49 & -2.45 & -7.67 & -7.54 \\
\end{tabular}

Note. The 5 percent critical values for the Phillips-Perron constant $=-2.95$, and for trend $=-3.54$.

\subsection{Cointegration Analysis}

Engle and Granger (1987) argue that finding integrating variables with the same order implies the possibility for these variables to be cointegrated. Hence, it would be useful to assess whether or not the variables falling under the scope of this study are cointegrated. This can be accomplished by relying on the trace and maximum eigenvalue tests developed by Johansen and Juselius (1990). As presented in Table (2), the results obtained from these tests point to the presence of a cointegrating relationship between economic growth and stock prices. This finding supports the notion of a relationship between stock market performance and real economic growth.

Table 2. Johansen and Juselius's (1990) Cointegration tests

\begin{tabular}{cccc}
\hline Null Hypothesis & Alternative Hypothesis & Test Statistics & 5\% Critical Value \\
\hline Panel A: Trace Test & & & 25.87 \\
\hline$r=0$ & $r=1$ & 29.51 & 12.15 \\
$r \leq 1$ & $r=2$ & 8.16 & 19.39 \\
\hline Panel B: Maximum Eigenvalue Test & & & 12.52 \\
\hline$r=0$ & $r=1$ & 21.35 & 8.16 \\
\hline
\end{tabular}

Note. $r$ denotes the number of cointegration vectors.

\subsubsection{Interpretation of the Cointegration Relationship}

Once the cointegration relationship between real stock prices and real economic growth is confirmed, it then becomes crucial to comprehend the dynamics of this relationship over both the short run and the long run. To do so, the long-run relationship, as specified in equation (1), is estimated by the maximum likelihood estimation (MLE) approach.

$$
G D P_{t}=\beta_{0}+\beta_{1} T A S I_{t}+\varepsilon_{t}
$$

where $G D P_{t}, T A S I_{t}$, and $\varepsilon_{t}$ represent the real non-oil GDP at time $t$, stock price index at time $t$, and the error term at time $t$, respectively. Likewise, $\beta_{0}$ denotes the constant term, while $\beta_{1}$ is the coefficient measuring how stock prices influence economic growth.

The estimated coefficients of equation (1), as shown in Table 3, reveal the important and significant role of stock market variation on economic growth. For further illustration, the real Saudi economy tends to grow by 3.2 percent due to the increase of stock prices by 10 percent. 
Table 3. Parameter estimates of long-run relationship

\begin{tabular}{lcc}
\hline & $\beta_{0}$ & $\beta_{1}$ \\
\hline Parameter estimates & $9.85^{*}$ & $0.32^{*}$ \\
$t$-value (Note 3) & & -3.79 \\
\hline
\end{tabular}

Note. The estimated model $G D P_{t}=\beta_{0}+\beta_{1} T A S I_{t}+\varepsilon_{t} *$ denotes a significance level of 5 percent.

Following the interpretation of the long-run relationship between economic growth and the stock market, it would be very informative for policymakers to gain some insight regarding the short-run dynamics between these variables. To provide such a valuable analysis, we need to estimate the following error correction model, specified by equation (2), based on the MLE procedure.

$$
\Delta G D P_{t}=\alpha_{0}+\sum_{i=1}^{s} \delta_{1 i} \Delta G D P_{t-i}+\sum_{i=1}^{s} \delta_{2 i} \Delta T A S I_{t-i}+\lambda E C M_{t-1}+\varepsilon_{t}
$$

where $\Delta G D P_{t}, \Delta T A S I_{t}$ and $\varepsilon_{t}$ are the changes in real economic growth (real non-oil GDP), changes in real stock market index, and the error term at time $t-1$, respectively. We rely on the Akaike information criterion (AIC) in order to determine the suitable lag length. It is also important to highlight that the error correction term is calculated from equation (1) as follows.

$$
E C M_{t-1}=G D P_{t-1}-\beta_{0}-\beta_{1} T A S I_{t-1}
$$

Once we derive the error correction term as specified in equation (3), we proceed to estimate the error correction model as specified in equation (2). The estimated parameters of the error correction model are presented in Table (4). The error correction term $(\lambda=-0.17)$ is negative and statistically significant, with a $t$-value equal to -2.79 confirming the presence of a long-run relationship and the essential role of the stock market in explaining the variation in real economic activity. It also implies that it takes the real economy about six quarters to adjust to its equilibrium condition, in the event that it deviates from its steady state.

The estimated coefficients for the other variables suggest that only changes in real stock prices (only with one lag) have a significant and negative impact on real economic activity during the short run; however, the impact becomes positive with four lags, although it is not statistically significant. It seems that changes in real stock prices have a positive impact on real economic activity over the long run, rather than the short run.

Table 4. Parameter estimates of error correction model

\begin{tabular}{ccc}
\hline Variables & Parameter Estimates & $t$-values \\
\hline Constant & $0.02^{* * *}$ & 3.16 \\
$\Delta G D P_{t-1}$ & -0.41 & -1.97 \\
$\Delta G D P_{t-2}$ & $-0.82^{* *}$ & -3.85 \\
$\Delta G D P_{t-3}$ & $-0.48^{* *}$ & -2.08 \\
$\Delta G D P_{t-4}$ & 0.07 & 0.03 \\
$\Delta S P_{t-1}$ & $-0.05^{* *}$ & -2.19 \\
$\Delta S P_{t-2}$ & -0.03 & 1.32 \\
$\Delta S P_{t-3}$ & -0.002 & -0.09 \\
$\Delta S P_{t-4}$ & 0.01 & 0.52 \\
$\lambda$ & -0.17 & $-2.8^{* *}$ \\
\hline
\end{tabular}

Note. $* *$ denotes a 5 percent significance level.

\subsection{Causality Analysis}

The estimated coefficients of the error correction model, particularly the error term coefficient, suggest that the stock market has predictive power in capturing changes in economic activity. For further assessment of such a finding, we apply the most popular causality test, known as the Granger (1969) causality test, which is built on the vector error correction model (VECM) since the variables are cointegrated. The basic intuition of this test is to gauge if the lagged values of certain variables could capture the movement of those variables. For further illustration, we need to estimate a bivariate VECM model consisting of real GDP and real TASI, as follows.

$$
\begin{aligned}
\Delta G D P_{t} & =\delta_{0}+\sum_{i=1}^{s} \delta_{1 i} \Delta G D P_{t-i}+\sum_{i=1}^{s} \delta_{2 i} \Delta T A S I_{t-i}+\lambda_{1} E C M_{t-1}+\epsilon_{1 t} \\
\Delta T A S I_{t} & =\varphi_{0}+\sum_{i=1}^{s} \varphi_{1 i} \Delta G D P_{t-i}+\sum_{i=1}^{s} \varphi_{2 i} \Delta T A S I_{t-i}+\lambda_{2} E C M_{t-1}+\epsilon_{2 t}
\end{aligned}
$$


where $\Delta$ denotes the change, while $G D P_{t}$ and $T A S I_{t}$ are the real GDP and the stock market price index of Saudi Arabia at time $t$, respectively. The error term $\epsilon_{1 t}$ is associated with equation (4), and $\epsilon_{2 t}$ is associated with equation (5). The lag length $S$ is chosen based on the AIC criteria. The coefficients $\delta_{0}, \delta_{1 i}, \delta_{2 i}, \varphi_{0}, \varphi_{1 i}$ and $\varphi_{2 i}$ are the estimates of the constants and the multiplicative factors for lagged economic growth and the stock price index. The estimated coefficients $\lambda_{1}$ and $\lambda_{2}$ represent the deviation of the dependent variables from the long-run equilibrium.

In order to determine if changes in real stock prices could capture changes in economic growth, we need to test if the hypothesis $\delta_{1 i}=\delta_{2 i}=0$ holds; in other words, we test the null hypothesis that changes in real economic activity do not Granger cause changes in the stock price index. Conversely, we test the null hypothesis that changes in the stock price index do not Granger cause changes in economic activity; that is to say, we test $\varphi_{1 i}=\varphi_{2 i}=0$. The obtained results of the Granger causality test, as shown in Table 5, suggest that changes in the stock market index do Granger cause changes in economic activity. In other words, the stock market plays an essential role in predicting economic cycles in Saudi Arabia, which is in line with various empirical studies on advanced and emerging countries. On the other hand, we fail to find empirical evidence in support of the notion that changes in real economic activity predict movements in the stock market. This might be attributed to the behavior of investors, who might choose alternative investment opportunities such as real estate investments or the money market, rather than the stock market; in sum, some investors prefer less risky financial assets.

Table 5. Results of Granger causality test based on VECM

\begin{tabular}{lcccc}
\hline Null Hypothesis & $\chi^{2}$ & $p$-value & ECM & \\
\hline $\begin{array}{l}\text { Dependent variable: GDP } \\
\Delta T \text { ASI does not Granger cause } \Delta \text { GDP }\end{array}$ & 11.9 & 0.02 & $0.17 *$ & Reject null hypothesis \\
\hline $\begin{array}{l}\text { Dependent variable: TASI } \\
\text { SGDP does not Granger cause } \triangle T \text { TSI }\end{array}$ & 3.84 & 0.43 & 0.78 & Fail to reject null hypothesis \\
\hline
\end{tabular}

\section{Conclusion}

This paper examines the causal relationship between stock market returns and economic activity in Saudi Arabia using various econometric techniques consisting of stationarity, cointegration, and causality analysis. The study is carried out using quarterly data of the Tadawul All Share Index (TASI) and the Saudi non-oil gross domestic product (GDP) from 2010:Q1 to 2018:Q4. By using Phillips and Perron's (1981) popular unit root test to ensure stationarity, it becomes apparent that the variables are stationary at first difference. Subsequently, the cointegration test used implies that there is a significant long-run relationship at 5 percent critical value between the two variables, as can be observed from the trace test as well as the maximum eigenvalue test in Table (2). The results obtained indicate that the tested relationship holds in the long run as well as in the short run, and there is in fact a unidirectional causality between TASI and economic growth in Saudi Arabia.

This study contributed to the existing literature by testing stock market performance and economic activity in Saudi Arabia. Nevertheless, there is a noticeable shortage of literature regarding this topic, and there is room to improve the existing literature. This study could lead to other hypotheses that can be taken into consideration, such as conducting a disaggregated analysis of the impact of stock market sub-indices on the corresponding disaggregated economic activities. Furthermore, we could not find any literature on the impact of stock market volatility on economic growth in Saudi Arabia. In addition, future studies could look at the impact of other indicators such as inflation, money supply, and fiscal and monetary policies on stock market performance, and vice versa.

\section{References}

Al Rasasi, M., Rawah, F., \& Alghamdi, B. (2019). On the nexus between stock market fluctuations and the demand for money in Saudi Arabia. SAMA Working Paper, 19/05

Alshogeathri, M. A. M. (2011). Macroeconomic determinants of the stock market movements: Empirical evidence from the Saudi stock market (Doctoral dissertation, Kansas State University).

Barro, R. J. (1990). The stock market and investment. The Review of Financial Studies, 3(1), 115-131. https://doi.org/10.1093/rfs/3.1.115

Basdas, U., \& Soytas, U. (2009). Do stock returns trigger economic growth? evidence from Turkey. 13. In the Annual International Conference on Macroeconomic Analysis and International Finance. 
Binswanger, M. (2000). Stock returns and real activity: Is there still a connection? Applied Financial Economics, 10(4), 379-387. https://doi.org/10.1080/09603100050031507

Binswanger, M. (2004). Stock returns and real activity in the G-7 countries: Did the relationship change during the 1980s? The Quarterly Review of Economics and Finance, 44(2), 237-252. https://doi.org/10.1016/j.qref.2003.07.001

Chatziantoniou, I., Duffy, D., \& Filis, G. (2013). Stock market response to monetary and fiscal policy shocks: Multi-country evidence. Economic Modelling, 30, 754-769. https://doi.org/10.1016/j.econmod.2012.10.005

Choi, J. J., Hauser, S., \& Kopecky, K. J. (1999). Does the stock market predict real activity? Time series evidence from the G-7 countries. Journal of Banking \& Finance, 23(12), 1771-1792. https://doi.org/10.1016/S0378-4266(99)00020-5

Duca, G. (2007). The relationship between the stock market and the economy: Experience from international financial markets. Bank of Valletta Review, 36(3), 1-12.

Engle, R.F., \& Granger, C.W.J. (1987). Co-integration and error correction: Representation, estimation, and testing. Econometrica, 55(2), 251-276. https://doi.org/10.2307/1913236

Fama, E. F. (1981). Stock returns, real activity, inflation, and money. The American Economic Review, 71(4), 545-565. https://doi.org/10.1111/j.1540-6261.1990.tb02428.x

Fama, E. F. (1990). Stock returns, expected returns, and real activity. The Journal of Finance, 45(4), 1089-1108. https://doi.org/10.1111/j.1540-6261.1983.tb03623.x

Gertler, M., \& Bernanke, B. (1989). Agency costs, net worth and business fluctuations. In Business Cycle Theory. Edward Elgar Publishing Ltd.

Geske, R., \& Roll, R. (1983). The fiscal and monetary linkage between stock returns and inflation. The Journal of Finance, 38(1), 1-33. https://doi.org/10.1111/j.1540-6261.1983.tb03623.x

Granger, C. W. J. (1969). Investigating the causal relations by econometric models and cross-spectral methods. Econometrica, 37(3), 424-438. https://doi.org/10.2307/1912791

Guo, Z. Y. (2017). How information is transmitted across the nations? An empirical investigation of the US and Chinese commodity markets. Global Journal of Management and Business Research. https://doi.org/10.2139/ssrn.3013797

Humpe, A., \& Macmillan, P. (2009). Can macroeconomic variables explain long-term stock market movements? A comparison of the US and Japan. Applied Financial Economics, 19(2), 111-119. https://doi.org/10.2139/ssrn.1026219

Ioannidis, C., \& Kontonikas, A. (2008). Monetary policy and the stock market: Some international evidence. UK: University of Bath and University of Glasgow. https://doi.org/10.1016/j.jpolmod.2007.06.015

Johansen, S., \& Juselius, K. (1990). Maximum likelihood estimated and inference on cointegration with application to the demand for money. Oxford Bulletin of Economics and Statistics, 52(2), 169-210. https://doi.org/10.1111/j.1468-0084.1990.mp52002003.x

Kalyanaraman, L., \& Al Tuwajri, B. (2014). Macroeconomic forces and stock prices: some empirical evidence from Saudi Arabia. International Journal of Financial Research, 5(1), 81-92. https://doi.org/10.5430/ijfr.v5n1p81

Kaplan, M. (2008). The impact of stock market on real economic activity: evidence from Turkey. Journal of Applied Sciences, 8(2), 374-378. https://doi.org/10.3923/jas.2008.374.378

Kiyotaki, N., \& Moore, J. (1997). Credit cycles. Journal of Political Economy, 105(2), 211-248. https://doi.org/10.1086/262072

Krchniva, K. (2016). Do Stock Markets Have Any Impact on Real Economic Activity? Acta Universitatis $\begin{array}{llll}\text { Agriculturae et Silviculturae Mendelianae } & \text { Brunensis, }\end{array}$ https://doi.org/10.11118/actaun201664010283

Lyócsa, S., Baumöhl, E., \& Výrost, T. (2011). The stock markets and real economic activity: New evidence from CEE. Eastern European Economics, 49(4), 6-23. https://doi.org/10.2753/EEE0012-8775490401

Manova, K. (2008). Credit constraints, equity market liberalizations and international trade. Journal of International Economics, 76(1), 33-47. https://doi.org/10.1016/j.jinteco.2008.03.008 
Mao, Y., \& Wu, R. (2007). Does the stock market act as a signal for real activity? Evidence from Australia. Economic Papers: A Journal of Applied Economics and Policy, 26(2), 180-192. https://doi.org/10.1111/j.1759-3441.2007.tb01015.x

Mauro, P. (2003). Stock returns and output growth in emerging and advanced economies. Journal of Development Economics, 71(1), 129-153. https://doi.org/10.1016/S0304-3878(02)00136-0

Mechri, N., Hamad, S. B., Peretti, C., \& Charfi, S. (2019). The Impact of the Exchange Rate Volatilities on Stock Market Returns Dynamic. https://doi.org/10.2139/ssrn.3304040

Modigliani, F. (1971). Monetary policy and consumption in Consumer spending and monetary policy: the linkages. In Federal Reserve Bank of Boston Conference Series (pp. 9-84).

Mohanty, S. K., Onochie, J., \& Alshehri, A. F. (2018). Asymmetric effects of oil shocks on stock market returns in Saudi Arabia: Evidence from industry level analysis. Review of Quantitative Finance and Accounting, 51(3), 595-619. https://doi.org/10.1007/s11156-017-0682-5

Phillips, P. C. B., \& Perron, P. (1988). Testing for unit roots in time series regression. Biometrika, 75(2), 335-346. https://doi.org/10.1093/biomet/75.2.335

Schwert, G. W. (1990). Stock returns and real activity: A century of evidence. The Journal of Finance, 45(4), 1237-1257. https://doi.org/10.1111/j.1540-6261.1990.tb02434.x

Tao, J., Ye, Q., \& Zhang, J. (2019). New Evidence on the Relations among Stock Returns, Inflation and Economic Activities. International Journal of Research, 6(2), 70-76.

Tobin, J. (1969). A general equilibrium approach to monetary theory. Journal of Money, Credit and Banking, 1(1), 15-29. https://doi.org/10.2307/1991374

Toda, H. Y., \& Yamamoto, T. (1995). Statistical inference in vector autoregressions with possibly integrated processes. Journal of Econometrics, 66(1-2), 225-250. https://doi.org/10.1016/0304-4076(94)01616-8

Tsouma, E. (2009). Stock returns and economic activity in mature and emerging markets. The Quarterly Review of Economics and Finance, 49(2), 668-685. https://doi.org/10.1016/j.qref.2008.02.002

\section{Notes}

Note 1. Higher internal financing plays an important role when external finance is unavailable or is available only at a high cost.

Note 2. A recent research paper by Al Rasasi et al. (2019) examines the effect of the stock market on the demand for money in Saudi Arabia.

Note 3. The Eviews software does not display the significance level of the constant term for the estimated cointegration relationship based on MLE. However, OLS estimates indicate the significance of the constant term.

\section{Copyrights}

Copyright for this article is retained by the author(s), with first publication rights granted to the journal.

This is an open-access article distributed under the terms and conditions of the Creative Commons Attribution license (http://creativecommons.org/licenses/by/4.0/). 